\title{
Longitudinal Analysis of Basic Motor and Functional Abilities of Elementary School Pupils
}

\author{
Ante Burger ${ }^{1}$, Endica Radić Hozo ${ }^{1}$, Vladimir Pavlinovićc ${ }^{2}$, Nikola Foretić ${ }^{2}$ \\ ${ }^{1}$ University of Split, University Department of Health Studies, Split, Croatia \\ ${ }^{2}$ University of Split, Faculty of Kinesiology, Split, Croatia
}

\begin{abstract}
A B S T R A C T
The aim of the research was to conduct a longitudinal study of motor and cardiorespiratory fitness of $5^{\text {th }}$ to $7^{\text {th }}$ grade elementary male and female pupils in the period from 2005 to 2020. The pupils (1649) were divided into 3 generation groups: the older (2005-2009), the middle (2010-2015) and the younger group (2016-2020). There is a noticeable decrease in flexibility among all pupils and grades of younger generations. Results indicate poorer performance of younger generation of 5th graders in speed and power. The 7th grade female pupils who were tested in the 2015 - 2020 period, showed a significant decline in all motor and cardiorespiratory fitness compared to the other two generation groups, except for upper body power. Every four years, an evaluation of test results should be carried out so that each Physical Education teacher in a particular school can accurately compare and standardise the obtained values.
\end{abstract}

Key words: longitudinal study, pupils, standardisation, teaching process, testing

\section{Introduction}

The teaching process in school education is an organised system of methodical and methodological procedures that aims to upgrade the pupils' knowledge and skills. School can be defined as a social institution whose basic task is to conduct organised educational work for members of a particular society ${ }^{1}$. Pajić Papak and Vidulin define school as an institution which delivers organised education of pupils ${ }^{2}$. Organised monitoring and observation of changes in motor and cardiorespiratory fitness in the Physical Education teaching is an important precondition for active syllabus planning. In their professional paper, Mraković et al. established a system of recording the physical condition and important anthropometric, motor, and functional characteristics of male and female pupils during their education ${ }^{3}$. Such a continuous approach to observing the physical condition of pupils enables a precise control of the teaching process. Longitudinal studies of this kind generally involve multiple measurements including the same group of respondents. Their aim is to record and describe a certain change that occurs over time and determine the direction and strength of the relationship between the tested variables. Findak defines motor abilities as latent motor structures responsible for an infinite number of manifest reactions that can be measured and described $^{4}$. Other experts, such as Kondrič ${ }^{5}$, describe motor abilities as a set of interrelated dimensions responsible for successfully overcoming motor ability problems, while Zatsiorsky defines them as aspects of intensity (strength or speed) and extensity (duration or number of repetitions) of motor activities that can be described by the same parametric system, measured and evaluated by an identical set of measures, with analogous operation of physiological, biochemical, morphological and biomechanical mechanisms ${ }^{6}$. Motor abilities cannot be effectively described by only one general dimension which requires a breakdown into several quantitative (strength, speed, stamina, and flexibility) and qualitative motor abilities such as coordination, balance, agility and precision ${ }^{7,8}$. Therefore, in this research, almost all motor abilities were observed in order to obtain a more quality overall perception of pupils. In addition to motor abilities, this scientific research also included the condition of functional abilities of $5^{\text {th }}$ grade male pupils. According to Milanović, functional abilities are related to the efficiency of oxygen transport systems (aerobic capacity) which ensure a constant supply of muscles and other organs with the necessary amount of energy required for the proper functioning and moderately intensive work ${ }^{9}$. Recently, there has been a noticeable decline in motor and cardiorespiratory fitness in school children ${ }^{10-12}$. Therefore, longitudinal studies of this kind are necessary in order to ensure a proper validation of the testing results of the observed abilities and to create the 
preconditions for precise syllabus planning. Syllabus planning is considered to be a process of designing the class, and teaching is considered a process of achieving changes in which the pupil is transferred from one state to the next altered state with a higher level of educational values ${ }^{13}$. Every kinesiologist has a responsibility to set up a quality framework of work based on precisely measured motor and cardiorespiratory fitness of their pupils. In order to achieve a precise syllabus planning, a population in a designated micro-area must be longitudinally observed to obtain relevant data that can be used for the purpose of standardising the observed abilities. The aim of this research is to conduct a longitudinal study of motor and cardiorespiratory fitness of $5^{\text {th }}$ to $7^{\text {th }}$ grade elementary male and female pupils in the period from 2005 to 2020 in the city area of Kaštela in the Split-Dalmatia County of Croatia.

\section{Methodology}

\section{Sample of respondents}

The study was conducted on a total sample of $\mathrm{n}=1649$ pupils in the $2005-2020$ period in the city area of Kaštela in the Split-Dalmatia County. It included $n=876$ male pupils and $n=766$ female pupils from $5^{\text {th }}$ to the $7^{\text {th }}$ grade. The pupils were divided into three groups according to the time they attended one of the tested classes in the school year: the older group (2005 - 2009), the middle group (2010 - 2015), and the younger group (2016 - 2020).

The following variables were observed: HEIGHT and WEIGHT were objectively measured in light clothing by using stadiometer and digital scale (Seca, Germany) with a precision of $0.1 \mathrm{~cm}$ and $0.1 \mathrm{~kg}$. CIRCUMFERENCE-the forearm girth circumference of each subject was measured using a flexible measuring tape (Seca, Germany) at a point $3 \mathrm{~cm}$ below the cubital fossa. TAPPING-for plate tapping the table height should be adjusted so that the subject is standing comfortably in front of the two yellow discs which are placed with their centres $60 \mathrm{~cm}$ apart on the table. The rectangle is placed equidistant between both discs. The non-preferred hand is placed on the rectangle. The subject moves the preferred hand back and forth between the discs over the hand in the middle as quickly as possible. This action is repeated for 25 full cycles (50 taps). LJUMP-in standing long jump each participant was instructed to stand on the starting line and perform standing long jump. The jumped distance was measured between the starting line and the closer heel upon touch-down. POLYGON - in polygon backwards subject had to crawl backwards and cover a 10-m distance. The starting position for the children was behind the starting line as the children faced backwards on all fours. The tester gave the starting signal. The test included backward crawling over and under the $35 \mathrm{~cm}$ high obstacles that were placed at $3 \mathrm{~m}$ and $6 \mathrm{~m}$ from the starting line. The task was measured in tenths of a second ( $0.1 \mathrm{~s})$. SITUP60 - sit-ups in 60 seconds children were seated on the floor, backs straight, hands clasped behind their neck, knees bent at $90^{\circ}$ with heels and feet flat on the mat. They then lay down on their backs, shoulders touching the mat, and returned to the sitting position with their elbows out in front to touch their knees, keeping the hands clasped behind their neck the whole time. FORWARD BEND seated wide-legged forward bend by sitting on the floor or a mat, legs straight under the angle of $90^{\circ}$, the child being tested reached forward with the arms (hands overlapping). The distance of reach was measured in centimetres using a measuring non-elastic tape attached on the floor. CHINUPH - static chin up hold - The child, with hands shoulder-width apart, grabs the bar. The teacher helps the kid to lift by holding him by the legs so that the chin reaches over the height of the bar. The child's body and legs are stretched vertically and his task in this position is to last as long as he can, and a maximum of 120 seconds. RUN_30 - running at 30 meters and RUN_60 - running at 60 meters - Children was instructed to stand on the starting line, one foot in front of the other, and run as fast as possible over finish line. The task was measured in tenths of a second (0.1 s), HJUMP - scissors high jump - children run in towards the mats and attempt to scissor up over the rubber band onto the mats, landing in an upright, standing position. MED BALL - throwing a $2 \mathrm{~kg}$ medicine ball - participants were required to sit on a chair with their shoulders in contact with the chair-back. They were then required to throw the medicine ball as far as possible, using chest pass technique. Metric characteristics of above-mentioned tests were confirmed by Findak et al. ${ }^{14}$

Statistical analysis included the computation of descriptive statistical parameters, while the normality of distribution was tested by the Kolmogorov-Smirnov test. After that, a multivariate variance analysis (MANOVA) was computed among three groups of respondents divided into older, middle, and younger group for each class. In addition, a univariate variance analysis (ANOVA) was conducted for male and female pupils to determine which variables show differences of results among the generational groups. All statistical computations were performed for both male and female pupils of $5^{\text {th }}, 6^{\text {th }}$ and $7^{\text {th }}$ grade. Software package STATISTIKA for Windows version 10 was used for statistical data processing.

\section{Results and Discussion}

The results in Table 1 indicate that the average height of $5^{\text {th }}$ grade male pupils is $149.28 \mathrm{~cm}$, while the average weight of male pupils is $44.06 \mathrm{~kg}$. Such results are correlated with the current literature review ${ }^{15}$. The mean value for the variable (LJUMP) is higher than the results obtained by Kocic et al. where the average value of the standing long jump was $145.3 \mathrm{~cm}$ for $5^{\text {th }}$ grade male pupils ${ }^{16}$. Exceptionally good results were achieved by $5^{\text {th }}$ grade male pupils in the variable (TAPPING) - plate tapping, where an average value of 29.99 was recorded, which is significantly more than reported in the research conducted by Mraković et al. ${ }^{3}$. The results obtained for the 
TABLE 1

DESCRIPTIVE STATISTICAL PARAMETERS FOR BOYS FROM 5TH TO 7TH GRADE

\begin{tabular}{lcccccc}
\hline \multirow{2}{*}{ VARIABLE } & \multicolumn{2}{c}{$5^{\text {th }}$ grade } & \multicolumn{2}{c}{$6^{\text {th }}$ grade } & \multicolumn{2}{c}{$7^{\text {th }}$ grade } \\
& AM & Std.Dev. & AM & Std.Dev. & AM & Std.Dev. \\
\hline HEIGHT & 149.28 & 7.66 & 156.14 & 8.08 & 163.16 & 9.33 \\
WEIGHT & 44.06 & 8.28 & 49.99 & 11.39 & 55.04 & 11.85 \\
CIRCUMFERENCE & 21.43 & 2.18 & 22.05 & 2.33 & 23.32 & 1.93 \\
TAPPING & 29.99 & 4.26 & 31.10 & 4.16 & 32.39 & 4.19 \\
LJUMP & 154.97 & 21.75 & 162.19 & 28.10 & 173.02 & 25.61 \\
POLYGON & 15.49 & 5.59 & 16.88 & 10.06 & 15.26 & 6.78 \\
SITUP60 & 34.83 & 8.28 & 39.06 & 9.17 & 42.27 & 8.88 \\
FORWARD BEND & 53.10 & 10.61 & 58.82 & 11.67 & 64.35 & 14.38 \\
CHINUPH & 23.48 & 19.00 & 22.39 & 18.24 & 29.46 & 20.69 \\
RUN_30 & 5.95 & 0,62 & 6.00 & 0.69 & 5.67 & 0.61 \\
RUN_60 & 11.56 & 1.21 & 11.59 & 1.27 & 10.75 & 1.42 \\
HJUMP & 96.02 & 11.82 & 98.13 & 12.53 & 105.19 & 12.02 \\
MED BALL & 7.65 & 1.68 & 8.30 & 1.76 & 8.87 & 4.03 \\
\hline
\end{tabular}

HEIGHT - body height, WEIGHT - body weight, CIRCUMFERENCE - forearm circumference, TAPPING - plate tapping, LJUMP - standing long jump, POLYGON - polygon backwards, SITUP60 - sit-ups in 60 seconds, FORWARD BEND - seated wide-legged forward bend, CHINUPH - static chin up hold, RUN_30 - running at 30 meters, RUN_60 - running at 60 meters, HJUMP - scissors high jump, MED BALL - throwing a $2 \mathrm{~kg}$ medicine ball, $\mathrm{n}=883$.

variable (POLYGON) for $6^{\text {th }}$ grade male pupils indicated poorer coordination compared to $5^{\text {th }}$ and $7^{\text {th }}$ grade male pupils. The research conducted by Badrić et al. did not indicate such results, hence it can be concluded that there is a decrease in coordination of male pupils due to entering puberty, a period which is marked by declining results in this motor ability ${ }^{17}$. Coordination as a motor ability is best developed in female pupils in the period from $1^{\text {st }}$ to $3^{\text {rd }}$ grade, while the peak is reached at the age of 11 . In male pupils, the process of peak coordination occurs between the ages of 12 and $13^{18}$.

The results in Table 2 descriptively explain the average values obtained from $5^{\text {th }}$ grade female pupils. The obtained results indicate the recorded average values for the variable (SITUP60) - sit-ups in 60 seconds, with the recorded 32.32 sit-ups. Such a substantial deviation of results is anticipated because today there are increasing differences

TABLE 2

DESCRIPTIVE STATISTICAL PARAMETERS FOR GIRLS FROM 5TH TO 7TH GRADE

\begin{tabular}{|c|c|c|c|c|c|c|}
\hline \multirow[t]{2}{*}{ VARIABLE } & \multicolumn{2}{|c|}{$5^{\text {th }}$ grade } & \multicolumn{2}{|c|}{$6^{\text {th }}$ grade } & \multicolumn{2}{|c|}{$7^{\text {th }}$ grade } \\
\hline & $\mathrm{AM}$ & Std.Dev. & $\mathrm{AM}$ & Std.Dev. & $\mathrm{AM}$ & Std.Dev. \\
\hline HEIGHT & 150.02 & 8.16 & 156.50 & 7.48 & 161.98 & 6.22 \\
\hline WEIGHT & 42.58 & 8.48 & 47.80 & 9.65 & 53.25 & 8.54 \\
\hline CIRCUMFERENCE & 21.09 & 3.35 & 24.08 & 24.18 & 22.38 & 1.61 \\
\hline TAPPING & 30.41 & 4.30 & 33.11 & 9.23 & 33.44 & 4.35 \\
\hline LJUMP & 146.05 & 22.05 & 151.80 & 22.94 & 159.30 & 20.86 \\
\hline POLYGON & 18.54 & 6.43 & 16.87 & 7.61 & 15.11 & 5.13 \\
\hline SITUP60 & 32.32 & 8.01 & 37.18 & 10.54 & 39.10 & 7.82 \\
\hline FORWARD BEND & 69.00 & 13.11 & 71.17 & 13.93 & 75.50 & 14.65 \\
\hline CHINUPH & 18.80 & 14.36 & 19.27 & 14.72 & 21.31 & 14.37 \\
\hline RUN_30 & 6.21 & 0.64 & 6.19 & 0.60 & 5.89 & 0.67 \\
\hline RUN_60 & 11.92 & 1.18 & 11.91 & 1.21 & 11.41 & 1.35 \\
\hline HJUMP & 88.40 & 10.45 & 93.18 & 11.54 & 96.10 & 12.86 \\
\hline MED BALL & 7.02 & 1.49 & 7.36 & 1.50 & 7.87 & 4.51 \\
\hline
\end{tabular}


in the results of children who attend any kind of professional training practice compared to those who do not engage in any sports activity. The average result of $7^{\text {th }}$ grade female pupils for the variable (FORWARD BEND) - seated wide-legged forward bend is $75.50 \mathrm{~cm}$, which is significantly higher than the average result of male pupils $64.35 \mathrm{~cm}$. With regard to gender, male pupils achieve better results in all tests compared to female pupils in the higher grades of elementary school, except for the flexibility test, which is confirmed by scientific research of this type conducted by Mladineo ${ }^{19}$ and Idrizović ${ }^{20}$.

Multivariate variance analysis of three groups of respondents in Table 3 indicates that there is a statistically significant difference between all groups of respondents within each class. The values thus obtained can be compared to the results obtained by Findak et al. and Badric et al. where a decrease in motor and cardiorespiratory fitness of male pupils from younger generations was not$\mathrm{ed}^{14,17}$. The genesis of the problem may be described by the fact that children today are less and less engaged in sports activities and are left to modern technologies that occupy a significant portion of the free time they once spent playing or training. Two teaching hours per week is too little time to encourage positive processes in the bodies of the pupils. Therefore, physical education teachers should en- courage children to enrol in extracurricular activities in order to accumulate the amount of time of engagement in sports-related activities, which ultimately yields significantly better results. The research conducted by Granić et al. and Džibrić et al. showed certain improvements in motor and cardiorespiratory fitness of male pupils engaged in extracurricular activities ${ }^{21,22}$.

The results of the univariate variance analysis of three groups of $5^{\text {th }}$ grade male pupils indicate that there is a statistically significant difference between these three observed groups for variables (TAPPING) - plate tapping, (HJUMP) - high jump, (MED BALL) - throwing a $2 \mathrm{~kg}$ medicine ball, (RUN_60) - running at 60 metres, and (CIRCUMFERENCE) - forearm circumference. The male pupils from the older generation who attended the $5^{\text {th }}$ grade in the period between 2005 and 2009 showed better results in the variable (HJUMP) - scissors high jump compared to the younger generation. On average, they were more successful by $4.54 \mathrm{~cm}$, whereas the male pupils of the younger generation $(2013-2020)$ were more successful in the variable (LJUMP) - standing long jump by $2.68 \mathrm{~cm}$. Prskalo and Sporiš explain that the purpose of the standing long jump is to estimate the explosive power that indicates the ability to activate the maximum number of motor units per unit of time in the realisation of simple

TABLE 3

MULTIVARIATE AND UNIVARIATE VARIANCE ANALYSIS OF THREE GROUPS OF MALE RESPONDENTS (OLDER GENERATION 2005 - 2009, MIDDLE GENERATION 2010 - 2014, AND YOUNGER GENERATION 2015 - 2020)

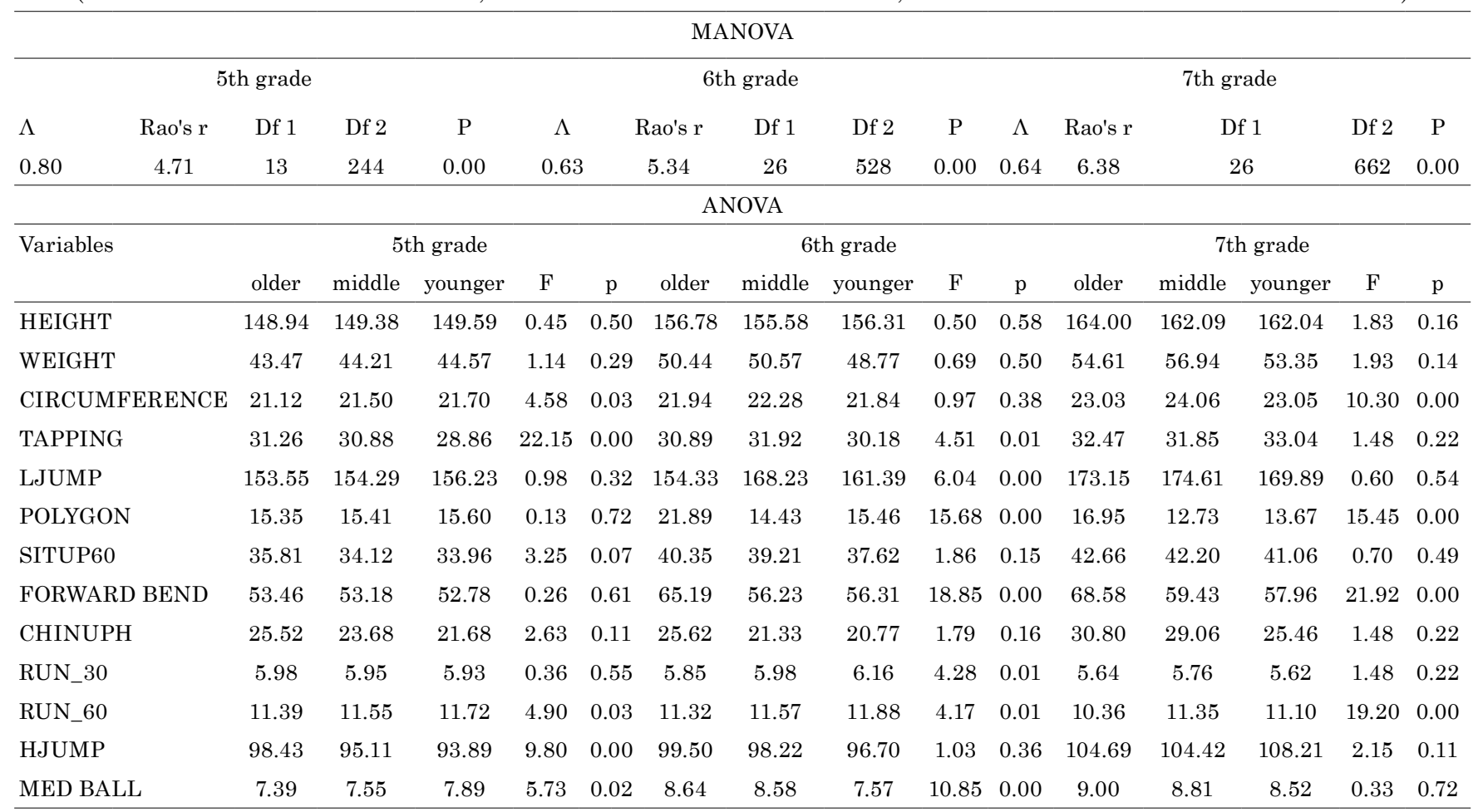

HEIGHT - body height, WEIGHT - body weight, CIRCUMFERENCE - forearm circumference, TAPPING - plate tapping, LJUMP - standing long jump, POLYGON - polygon backwards, SITUP60 - sit-ups in 60 seconds, FORWARD BEND - seated wide-legged forward bend, CHINUPH static chin up hold, RUN_30 - running at 30 meters, RUN_60 - running at 60 meters, HJUMP - scissors high jump, MED BALL - throwing a 2 $\mathrm{kg}$ medicine ball, $\mathrm{n}=883$. 
motor structures with constant resistance or resistance proportional to body mass ${ }^{23}$. The results thus obtained may be explained by the fact that a higher number of repetitions is required for a more successful performance of the scissors high jump. A quality scissors high jump requires a good technical training of movement in order to achieve the maximum result. The results obtained among the $6^{\text {th }}$ grade male pupils indicate that the middle group $(2010$ - 2014) was more successful in the variables (TAPPING, LJUMP and POLYGON). The analysis of the results shows that there is a significant decrease in the flexibility of male pupils from younger generations (2015 - 2020). Currently, there is an unfavourable trend among the younger generations of lesser engagement in kinesiological activities. The research conducted by Jureša et al. indicates that there is an increasing prevalence and insufficient physical activity among both male and female pupils in Croatian schools ${ }^{24}$. Accordingly, there is a decline in motor abilities due to inactivity, which greatly affects the development of motor abilities.
Fifth, sixth and seventh grade female pupils were divided into three generational groups, and the results of the multivariate analysis (MANOVA) showed that there are differences between the groups. Table 4 indicates that the statistically most significant difference between the groups of $5^{\text {th }}$ grade female pupils was recorded for the variables (TAPPING) - plate tapping, (FORWARD BEND) - seated wide-legged forward bend, (POLYGON) - polygon backwards, and (RUN_60) - running at 60 meters. Older generations of female pupils have, on average, achieved better results compared to the younger ones, except for the variable (POLYGON) - polygon backwards. Such results were not expected because the research conducted by Prskalo et al. showed that the younger generations had poorer performance compared to the older ones in this motor ability ${ }^{25}$. The reason for such results may be found in fatigue during testing performed at the end of the lesson, which ultimately affected the test results. In terms of $7^{\text {th }}$ grade female pupils who were tested in the $2015-$ 2020 period, the results showed a significant decline in all

TABLE 4

MULTIVARIATE AND UNIVARIATE VARIANCE ANALYSIS OF THREE GROUPS OF FEMALE RESPONDENTS (OLDER GENERATION 2005 - 2009, MIDDLE GENERATION 2010 - 2014, AND YOUNGER GENERATION 2015 - 2020)

\begin{tabular}{|c|c|c|c|c|c|c|c|c|c|c|c|c|c|c|c|}
\hline \multicolumn{16}{|c|}{ MANOVA } \\
\hline \multicolumn{4}{|c|}{5 th grade } & \multicolumn{6}{|c|}{6 th grade } & \multicolumn{6}{|c|}{ 7th grade } \\
\hline Rao's r & Df 1 & Df 2 & $\mathrm{P}$ & \multicolumn{2}{|c|}{$\Lambda$} & Rao's $\mathrm{r}$ & Df 1 & Df 2 & $\mathrm{P}$ & \multicolumn{2}{|r|}{$\Lambda$} & Rao's r & Df 1 & Df 2 & $\mathrm{P}$ \\
\hline 4.86 & 26 & 494 & 0.00 & \multicolumn{2}{|c|}{0.64} & 4.12 & 26 & 424 & 0.00 & \multicolumn{2}{|c|}{0.69} & 4.07 & 26 & 524 & 0.00 \\
\hline \multicolumn{16}{|c|}{ ANOVA } \\
\hline \multirow{2}{*}{ Variables } & \multicolumn{5}{|c|}{5 th grade } & \multicolumn{5}{|c|}{6 th grade } & \multicolumn{5}{|c|}{7 th grade } \\
\hline & older & middle & younger & $\mathrm{F}$ & $\mathrm{p}$ & older & middle & younger & $\mathrm{F}$ & $\mathrm{p}$ & older & middle & younger & $\mathrm{F}$ & $\mathrm{p}$ \\
\hline HEIGHT & 150.40 & 149.13 & 150.64 & 0.92 & 0.40 & 154.84 & 158.03 & 156.78 & 1.50 & 0.23 & 161.87 & 161.43 & 163.23 & 1.50 & 0.23 \\
\hline WEIGHT & 41.44 & 42.98 & 43.04 & 0.89 & 0.41 & 44.26 & 51.77 & 47.74 & 3.37 & 0.03 & 51.85 & 54.28 & 54.82 & 3.37 & 0.03 \\
\hline CIRCUMFERENCE & 21.32 & 21.07 & 20.94 & 0.27 & 0.76 & 25.33 & 25.41 & 21.72 & 0.50 & 0.00 & 22.28 & 22.48 & 22.43 & 0.50 & 0.60 \\
\hline TAPPING & 30.31 & 31.54 & 29.33 & 6.59 & 0.00 & 35.36 & 33.14 & 30.91 & 7.36 & 0.00 & 34.49 & 32.48 & 32.60 & 7.36 & 0.00 \\
\hline LJUMP & 146.79 & 146.52 & 144.99 & 0.17 & 0.84 & 153.25 & 148.60 & 153.21 & 2.37 & 0.09 & 160.57 & 160.68 & 153.72 & 2.37 & 0.09 \\
\hline POLYGON & 21.16 & 16.05 & 19.08 & 15.02 & 0.00 & 19.21 & 14.26 & 16.89 & 6.83 & 0.00 & 14.58 & 14.54 & 17.40 & 6.83 & 0.00 \\
\hline SITUP60 & 33.42 & 33.21 & 30.57 & 3.57 & 0.03 & 39.64 & 38.01 & 34.09 & 0.90 & 0.40 & 38.66 & 39.97 & 38.60 & 0.90 & 0.40 \\
\hline FORWARD BEND & 75.43 & 65.80 & 67.34 & 13.44 & 0.00 & 71.73 & 70.03 & 71.63 & 2.48 & 0.08 & 77.32 & 72.94 & 75.66 & 2.48 & 0.08 \\
\hline CHINUPH & 20.11 & 20.09 & 16.47 & 1.94 & 0.15 & 20.51 & 18.89 & 18.39 & 1.07 & 0.34 & 22.58 & 20.61 & 19.44 & 1.07 & 0.34 \\
\hline RUN_30 & 6.14 & 6.31 & 6.15 & 2.08 & 0.13 & 6.10 & 6.35 & 6.13 & 11.35 & 0.00 & 5.70 & 5.99 & 6.17 & 11.35 & 0.00 \\
\hline RUN_60 & 11.59 & 11.86 & 12.23 & 6.62 & 0.00 & 11.77 & 12.07 & 11.91 & 19.42 & 0.00 & 10.91 & 11.76 & 12.00 & 19.42 & 0.00 \\
\hline HJUMP & 88.47 & 87.81 & 88.94 & 0.28 & 0.76 & 94.68 & 91.93 & 92.83 & 3.63 & 0.02 & 98.06 & 93.42 & 96.13 & 3.63 & 0.02 \\
\hline MED BALL & 7.13 & 6.82 & 7.16 & 1.48 & 0.23 & 7.57 & 7.54 & 7.00 & 1.53 & 0.21 & 7.46 & 7.94 & 8.73 & 1.53 & 0.21 \\
\hline
\end{tabular}

HEIGHT - body height, WEIGHT - body weight, CIRCUMFERENCE - forearm circumference, TAPPING - plate tapping, LJUMP - standing long jump, POLYGON - polygon backwards, SITUP60 - sit-ups in 60 seconds, FORWARD BEND - seated wide-legged forward bend, CHINUPH - static chin up hold, RUN_30 - running at 30 meters, RUN_60 - running at 60 meters, HJUMP - scissors high jump, MED BALL - throwing a $2 \mathrm{~kg}$ medicine ball, $\mathrm{n}=766$. 
motor and cardiorespiratory fitness compared to the other two generational groups, except for the variable MED BALL - throwing a $2 \mathrm{~kg}$ medicine ball. As the highest average body weight and height were recorded in female pupils of this generational group, such results are correlated with the research conducted by Winter et al., Neville et al., and Dore et al. who found that strength and power were partially strongly related to body size when the results were expressed in absolute values ${ }^{26-28}$.

\section{Conclusion}

The younger generations of pupils in both genders perform poorer results in motor abilities and cardiorespiratory fitness tests. Obviously, poorer results are connected with general change of pupils' lifestyle that leads to motor and cardiorespiratory deficiency even in teenage years.

\section{R E F E R E N C E S}

1. VRCELJ S, Što školu čini školom; teorijski pristupi, koncepti i trendovi (Faculty of Humanities and Social Sciences, Rijeka, 2018) - 2 . PEJIĆ PAPAK P, I VIDULIN S, Izvannastavne aktivnosti u suvremenoj školi (Školska knjiga, Zagreb, 1981). — 3. MRAKOVIĆ M, FINDAK V, GAGRO I, JURAS V, RELJIĆ J, Metodologija praćenja i vrednovanja u zdravstvenom odgojno - obrazovnom području (JUMENA, Zagreb, 1986). — 4. FINDAK V, Metodika tjelesne i zdravstvene culture (Školska knjiga, Zagreb, 2003). - 5. KONDRIČ M, Promjene odnosa između nekih antropometrijskih osobina i motoričkih sposobnosti učenika od 7. do 18. godine. PhD thesis. (University of Zagreb, Zagreb, 2000). - 6. ZATSIORSKY VM, Kinetics of human motion (Human Kinetics, Champaign, 2002). - 7. MILANOVIĆ L, Trening snage djece i mladih - najčešće dvojbe. In: JUKIĆ I, MILANOVIĆ D, GREGOV C (Eds): Proceedings of Fitness Training of Athletes (Faculty of Kinesiology, Zagreb, 2008). - 8 . MILANOVIĆ D, Teorija i metodika treninga, 2. dopunjeno izmijenjeno izdanje (Faculty of Kinesiology, Zagreb 2009). — 9. MILANOVIĆ D, Teorija treninga (Faculty of Kinesiology Zagreb, 2013). - 10. HARDMAN K, Kinesiology, 40 (2008) 5. - 11. PETRIĆ V, Povezanost indeksa tjelesne mase i funkcionalnih sposobnosti te razlike $u$ istima između učenika urbanih naselja i ruralnih sredina. In: NELJAK B (Ed): Proceedings of the 18th Summer School of Kinesiologists of Republic of Croatia (Hrvatski kineziološki savez, Zagreb, 2009). - 12. JELČIĆ M, Komparativna analiza motoričkih sposobnosti učenika požeške regije s normama Republike Hrvatske. MSc Thesis (University of Zagreb, Zagreb, 2019). - 13. NELJAK B, Kineziološka metodika u osnovnom i srednjem školstvu (Gopal d.o.o., Zagreb, 2013). - 14. FINDAK V, METIKOŠ D, MRAKOVIĆ M, Orijentacijske norme motoričkih i funkcionalnih sposobnosti učenika 5. - 8. razreda osnovne škole. In: FINDAK V (Ed): Proceedings of AlpeJadran Sports Conference (Faculty of Kinesiology, Zagreb, 1993). - 15. NELJAK B, FINDAK V, NOVAK D, Differences in the final testing results of pupils between the two relatively close time instants. In: MILANOVIĆ D, PROT F (Ed): Proceedings of the 5th International Sci-
Several recommendations could be given accordingly; 1) it is necessary to structure new uniform test values applicable to the entire territory of the Republic of Croatia, 2) kinesiologist working as physical education teachers should periodically, preferably every four years, prepare new standards for their tests due to deviations in results and the deteriorating performance of younger generation pupils, 3) a possible extension of this research would be if these results were compared to studies conducted in other schools on the same population and other geographical areas in the Republic of Croatia. The probability of deviation of results between different geographical regions is quite possible, hence such studies should be conducted in one of the forthcoming research of this type to ensure accuracy, precision and validation of measurements and 4) it would be recommended to prepare new value standards of results every four years because there are discrepancies in test results that were performed several decades ago.

entific Conference on Kinesiology "Kinesiology research trends and applications" (Faculty of Kinesiology, University of Zagreb, 2008). - 16. KOCIĆ J, STOJANOVIĆ D, STANKOVIĆ S, PETROVIĆ L, IGNJATOVIAĆ A, SAVIĆ Z, MILENKOVIĆ V, STOJANOVIĆ T, MOMČILOVIĆ Z, Acta Medica Medianae, 58 (2019), 154. doi:10.5633/ amm.2019.0223 - 17. BADRIĆ M, SPORIŠ G, KRSTIČEVIĆ T, Hrvat. Športskmed. Vjesn., 30 (2015) 92. - 18. FACH HH, Trainingsbuch Bauchmuskulator (Verlag GmbH, Reinbek bei Hamburg, 1998). - 19. MLADINEO M, Različitosti između dječaka i djevojčica petih razreda u nekim motoričkim sposobnostima. In: FINDAK V (Ed): Proceedings of the 15th Summer School of Kinesiologists of Republic of Croatia (Hrvatski kineziološki savez, Zagreb, 2006). - 20. IDRIZOVIĆ K, Razlike u dinamici razvoja motoričkih sposobnosti dječaka i djevojčica. In: FINDAK V (Ed): Proceedings of the 22nd Summer School of Kinesiologists of Republic of Croatia (Hrvatski kineziološki savez, Zagreb, 2013). - 21. GRANIĆ I, KRISTIĆ T, Razlike u nekim antropometrijskim, motoričkim i funkcionalnim varijablama između mladih košarkaša i učenika osmih razreda. In: FINDAK V (Ed): Proceedings of the 15th Summer School of Kinesiologists of Republic of Croatia (Hrvatski kineziološki savez, Zagreb, 2006). — 22. DŽIBRIĆ DŽ, FERHATBEGOVIĆ A, POJSKIĆ H, Efekti programa izvannastavnih tjelesnih aktivnosti na transformaciju motoričkih sposobnosti učenika srednjoškolskog uzrasta. In: FINDAK V (Ed): Proceedings of the 22nd Summer School of Kinesiologists of Republic of Croatia (Hrvatski kineziološki savez, Zagreb, 2013). — 23. PRSKALO I, SPORIŠ G, Kineziologija, (Školska knjiga, Zagreb, 2016). - 24. JUREŠA V, MUSLI V, MAJER M, PETROVIĆ D, Medicus, 19 (2010) 35. — 25. PRSKALO I, NEDIĆ A, SPORIŠ G, BADRIĆ M, MILANOVIĆ N, Hrvat. Športskmed. Vjesn, 26 (2011) 100. - 26. WINTER EM, BROOKES FB, HAMLEY EJ, J. Sports Sci, 9 (1991) 3. — 27. NEVILL AM, RAMSBOTTOM R, WILLIAMS C, Eur. J. Appl. Physiol, 65 (1992) 110. - 28. DORE E, DIALLO O, FRANCA NM, BEDU M, VAN PRAAGH E. Int. J. Sports Med., 21 (2000) 360.

\section{N. Foretić}

University of Split, Faculty of Kinesiology, Ul. Nikole Tesle 6, 21000 Split, Croatia

e-mail: nikolaforetic@gmail.com 


\section{LONGITUDINALNALNA ANALIZA REZULTATA DOBIVENIH MJERENJEM BAZIČNIH MOTORIČKIH I FUNKCIONALNIH SPOSOBNOSTI KOD UČENIKA I UČENICA OD 5. DO 7. RAZREDA OSNOVNE ŠKOLE NA PODRUČJU GRADA KAŠTELA}

\section{S A Ž E T A K}

Cilj ovog istraživanja bio napraviti longitudinalno istraživanje motoričkih i funkcionalnih sposobnosti u vremenskom razdoblju od 2005. do 2020. godine nad učenicima i učenicama od 5. do 7. razreda osnovnih škola na području grada Kaštela u Splitsko-dalmatinskoj županiji. Testiranje je provedeno na n=1649 učenika koji su bili podijeljeni po spolu. Prvo je napravljena deskriptivna analiza za sve grupe učenika i učenica. Nakon toga je izračunata multivarijatna i univarijatna analiza varijance. Učenici su podijeljeni u 3 skupine u odnosu kada je obavljeno testiranje: stariju skupinu (2005-2009), srednju skupinu (2010-2015) i mlađu skupinu (2016-2020). Dobiveni izračuni ukazuju da je kod svih učenika, u svim razredima primjetno opadanje fleksibilnosti kod novijih generacija učenika. Dobiveni rezultati ukazuju na nešto lošije rezultate učenika petih razreda mlađe generacije (2015-2020) za varijable TAPING-taping rukom, TRC ᄀר_60- trčanje na 60 metara i SKOK_VIS-skok u vis prekoračnom tehnikom. Kod učenica sedmog razreda koje su testirane u vremenskom period od (2015-2020) rezultati su pokazali značajno opadanje svih motoričkih i funkcionalnih sposobnosti u odnosu na druge dvije generacijske skupine, osim za varijablu bacanje medicinke od 2kg (MEDICINK). Svako četiri godine trebalo bi provesti evaluaciju dobivenih rezultata testiranjem kako bi svaki nastavnik u određenoj školi mogao precizno komparirati i normirati dobivene vrijednosti. Stoga je i cilj ovog istraživanja bio analizirati testiranja koja su obavljena u dužem vremenskom periodu te postaviti smjernice plana i programa rada kao i preduvjete za kvalitetno normiranje motoričkih postignuća kod učenika. 
